\title{
PENGEMBANGAN PENANDA MOLEKULER BERDASARKAN SITUS SNP DAN INDEL GENOM KLOROPLAS KELAPA
}

\author{
Development of Molecular Marker Based on SNP sites and Indel in Coconut Chloroplast \\ Genome
}

\author{
Freta Kirana Balladona $^{1 *}$, Ismail Maskromo², Dewi Sukma ${ }^{1}$, Sudarsono $^{1}$ \\ ${ }^{1}$ Departemen Agronomi dan Hortikultura Fakultas Pertanian, Institut Pertanian Bogor, \\ Jln. Meranti-Kampus Darmaga, Bogor 16680, Indonesia \\ ${ }^{2}$ Balai Penelitian Tanaman Palma \\ Jalan Raya Mapanget, Kotak Pos 1004, Manado 95001 \\ *Email: fretaballadona@gmail.com
}

Diterima 1 Juni 2019/Disetujui 12 Maret 2020

\begin{abstract}
ABSTRAK
Saat ini informasi dasar mengenai silsilah, keragaman dan hubungan evolusi kekerabatan menggunakan marka molekuler pada kelapa di Indonesia masih kurang. Hal ini dibuktikan dengan belum banyak dilaporkan urutan sekuens genom kelapa Indonesia yang dapat dijadikan dasar dalam pembuatan marka molekuler tersebut. Salah satu genom tanaman yang dapat dimanfaatkan sebagai penanda adalah sekuens genom kloroplas (cpDNA). Genom kloroplas merupakan penanda yang efisien untuk mempelajari evolusi dan sejarah populasi tanaman melalui filogenetik karena bersifat sangat konservatif, diwariskan secara maternal, memiliki ukuran yang lebih kecil dibandingkan dengan genom inti. Tujuan dari penelitian ini adalah pengembangan primer berdasarkan genom kloroplas berbasis situ SNP dan indels. Berdasarkan sembilan sekuens genom kloroplas pada tanaman palma, telah berhasil didisain 10 primer berdasarkan situs SNP dan 5 primer berdasarkan situs insersi delesi. Hasil validasi primer tersebut menggunakan DNA kelapa Indonesia didapatkan hasil bahwa 10 primer SNP berhasil teramplifikasi sedangkan indels hanya 2 primer berbasis PCR.
\end{abstract}

Kata kunci: dalam, genjah, SNAP, primer

\section{ABSTRACT}

Nowadays, the basic information about family tree diversity and the relationship of evolution of kinship using molecular markers on coconut in Indonesia is still lacking. This is proofed by the fact that there is not many reported sequences of Indonesian coconut genomes, which can be used as a basic for making molecular markers. One of the plant genomes that can be used as a marker is the chloroplast (cpDNA) genome sequence. The chloroplast genome is an efficient marker for studying the evolution and history of plant populations through phylogenetics because it is very conservative, inherited maternally, has a smaller size compared to the core genome. The purpose of the study is development of molecular marker based on SNP sites and Indel in coconut chloroplast genome. Based on the nine chloroplasts genome sequences in palm plants, 10 primers were successfully designed based on SNP sites and 5 primers based on deletion insertion sites. The results of the primary validation using Indonesian coconut DNA showed that 10 SNP primers were successfully amplified while indels were only 2 primers PCR based. 


\section{PENDAHULUAN}

Keberadaan kelapa yang memiliki nilai sejarah yang tidak lepas dari perkembangan peradaban masyarakat di daerah tropis. Baik secara historis maupun saat ini, kelapa memiliki banyak kegunaan yaitu sebagai sumber makanan, minuman dan bahan bakar. Bahkan semua bagian tanaman tersebut dapat dimanfaatkan (Gunn 2016).

Produksi kelapa dari tahun ke tahun mengalami penurunan karena berbagai alasan namun masih bernilai ekonomi yang penting dengan adanya permintaan industri yang tinggi (Larekeng 2015). Penurunan tersebut akibat dari rendahnya produktivitas dengan rata-rata $1 \mathrm{t}$ kopra/ha/tahun padahal potensi produksi kelapa dapat mencapai 3-5 $\mathrm{t}$ kopra/ha/tahun (Pesik 2016). Banyak faktor yang mempengaruhi hal tersebut, diantaranya adalah faktor lingkungan yaitu kekeringan, bencana alam, hama dan penyakit serta persaingan dari minyak nabati dari komoditas lainnya menyebabkan kelapa ditinggalkan. Faktor lainnya adalah pohon kelapa yang telah ditanam sejak lama dan belum dilakukan peremajaan dan rehabilitasi, erosi genetik serta ketersediaan varietas kelapa unggul yang memiliki produktivitas yang tinggi dan mampu beradaptasi dengan baik (Batugal et al. 2005). Oleh karena itu, salah satu cara untuk mengatasi berbagai permasalah tersebut adalah dengan menggunakan varietas unggul.

Perakitan varietas unggul dapat dilakukan dengan program pemuliaan tanaman. Salah satu contohnya adalah kelapa hibrida yang memiliki karakter pohon yang pendek, cepat berbuah dan memiliki kadar minyak yang tinggi (Novarianto 2010). Metode pemuliaan tanaman yang dilakukan adalah seleksi dan hibrididasi untuk merakit berbagai jenis kelapa hibrida, terutama kelapa hibrida hasil persilangan antar kelapa Genjah x kelapa Dalam (Novarianto 2008). Kegiatan pemuliaan seperti seleksi, hibridisasi dan penyebaran tanaman yang terus menerus
(Loiola et al. 2016) serta kondisi geologi dan iklim yang bervariasi akan mengakibatkan terbentuknya aliran gen di dalam populasi, kerusakan genetik dan juga terbentuknya keterkaitan adanya hubungan antar tanaman (Jia et al. 2016). Hal ini juga akan mempengaruhi pada proses evolusi biologi yang dialami oleh tanaman tersebut. Untuk mempelajari kontrol pewarisan suatu karakter pada tanaman, maka diperlukan silsilah yang lengkap dan jelas asal usul persilangan pada setiap generasi (Pesik 2016).

Saat ini informasi dasar mengenai silsilah, keragaman dan hubungan evolusi kekerabatan menggunakan marka molekuler pada kelapa di Indonesia masih kurang. Hal ini dibuktikan dengan belum banyak dilaporkan urutan sekuens genom kelapa Indonesia yang dapat dijadikan dasar dalam pembuatan marka molekuler tersebut. Salah satu genom tanaman yang dapat dimanfaatkan sebagai penanda adalah sekuens genom kloroplas (cpDNA). Genom kloroplas merupakan penanda yang efisien untuk mempelajari evolusi dan sejarah populasi tanaman melalui filogenetik karena bersifat sangat konservatif, diwariskan secara maternal, memiliki ukuran yang lebih kecil dibandingkan dengan genom inti (Dauby et al. 2010).

Genom kloroplas dapat dimanfaatkan dalam pembentukan marka molekuler SNAP (Single Nucleotide Amplified Polymorphism). Marka SNAP adalah marka berdasarkan variasi perubahan satu basa (A, T, G, C) pada situs-situs tertentu dari runutan basa DNA dalam genom organisme (Ganal et al. 2009). Polimorfisme SNP tersedia melimpah dan terdistribusi secara merata pada genom organisme hidup sehingga mudah dimanfaatkan dalam analisis untuk mengidentifikasi keragaman yang tinggi (Peterson et al. 2014). Marka DNA berbasis SNAP adalah satu-satunya marka DNA yang memiliki sifat bi-alel dan ko-dominan, sehingga mampu membedakan alel homozigot dari heterozigot yang efisien (Hu et al. 2015). Marka SNAP juga terbukti 
menghasilkan kualitas data yang lebih baik dari sejumlah besar sampel pada penelitian genetika dan evolusi (Ren et al. 2013).

Saat ini telah dikembangkan oleh Pesik (2016) marka SNAP berbasis gen WRKY, SUS, SACPD dan ABI3 dalam riset pada populasi kelapa Indonesia yang diperoleh dari bank data yang sudah tersedia. Namun, pengembangan penanda genom kloroplas (cpDNA) berbasis SNAP belum ada, begitu pula dengan berbasis insersi delesi atau Indels. Indels merupakan penanda genetik berbasis urutan lainnya seperti SSR dan SNPs dan dikenal sebagai sistem penanda yang efektif untuk analisis genetika pada tanaman terutama yang bersifat multi-allelic dan co-dominant dan distribusi genetika yang luas. Selain itu, penanda InDel mudah terdeteksi pada skala genom (tingkat gen) dengan biaya rendah, tenaga kerja dan waktu melalui perbandingan sumber genomik (transkriptom) yang dapat diakses secara bebas dari genotipe yang tersedia melalui alat genetika komputasi (Das et al. 2015). Berdasarkan alasan-alasan tersebut indels dapat dijadikan alternatif sebagai penanda molekuler yang lebih efektif.

Maka dari itu identifikasi kekerabatan serta hubungan evolusi kelapa di Indonesia menggunakan marka molekuler khususnya genom kloroplas (cpDNA) berbasis SNAP merupakan alat bantu yang stategis yang dapat mempersingkat waktu seleksi, sehingga dapat mempercepat pencapaian tujuan pemuliaan tanaman, untuk menyediakan sumberdaya genetik yang memiliki karakter unggul dalam waktu yang singkat. Jadi tujuan dari penelitian ini adalah pengembangan primer berdasarkan genom kloroplas berbasis situ SNP dan indels.

\section{BAHAN DAN METODE}

Penelitian ini dilaksanakan pada Bulan Mei-September 2017 (In silico) hingga Juli 2018 di Laboraturium Plant Molecular Biology (PMB) I Fakultas Pertanian, Institut Pertanian Bogor.
Desain primer genom kloroplas dilakukan dengan mengakses data sekuens cpDNA tanaman palma pada bank data (https://www.ncbi.nlm.nih.gov/) dan sekuens genom kloroplas kelapa Indonesia yang telah dikembangkan (personal communication) yang digunakan untuk mendesain primer SNAP. Setiap sekuens dalam kelompok gen disusun dalam file teks menurut format Fasta. Sekuens disejajarkan menggunakan multiple alignment untuk mengidentifikasi letak satu basa nukleotida yang berbeda menggunakan program Geneious Pro 5.6.6 versi percobaan (Biomatters, USA).

Hasil multiple alignment cpDNA disubmit secara online menggunakan program WebSNAPER pada situs http://ausubellab.mgh. harvard.edu. Setiap submit hanya mendefinisikan satu titik SNP, sehingga untuk titik SNP lain maka submit dilakukan berulang. Masing-masing hasil desain untuk setiap situs SNP dipilih dua set (empat primer) yang terdiri atas satu set (sepasang primer) untuk alel referensi (R) dan satu set untuk alel alternatif (A). Setelah diperoleh runutan primer dilanjutkan dengan pemilihan primer sesuai dengan jumlah situs SNP.

Desain primer genom kloroplas dilakukan dengan mengakses data sekuens cpDNA tanaman palma pada bank data, sekuens genom kloroplas kelapa Indonesia yang telah dikembangkan yang berasal dari Indonesia yang digunakan untuk mendesain primer SNAP. Setiap sekuens dalam kelompok gen disusun dalam file teks menurut format Fasta. Sekuens disejajarkan menggunakan multiple alignment untuk mengidentifikasi letak satu basa nukleotida yang berbeda menggunakan program GENEIOUS. Hasil multiple alignment cpDNA yaitu keberadaan inserdi-delesi pada genom kloroplas tersebut, disubmit secara online menggunakan program Primer3plus pada situs http://www. bioinformatics.nl/cgibin/primer3plus/prime r 3plus.cgi

Primer SNAP dan Indels diuji kemampuannya untuk menghasilkan 
produk amplifikasi menggunakan DNA yang telah diisolasi sebelumnya yaitu 1 genotipe kelapa Morotai dan 1 genotipe kelapa unggul Indonesia dengan reaksi singleplex PCR. Suhu annealing primer SNAP dioptimasi menggunakan gradien thermocycling PCR untuk meningkatkan efisiensi PCR. Kombinasi suhu yang digunakan adalah $48.0^{\circ} \mathrm{C}, 49.5^{\circ} \mathrm{C}, 52.8^{\circ} \mathrm{C}$, $54.6^{\circ} \mathrm{C}, \quad 56.4^{\circ} \mathrm{C}, \quad 58.2^{\circ} \mathrm{C}$ dan $60.0^{\circ} \mathrm{C}$. Amplifikasi DNA dilakukan dengan menggunakan KAPA2 ${ }^{\mathrm{TM}}$ PCR kit (Kapa Biosystems Inc., USA). Komposisi reaksi singleplex terdiri atas $6.25 \mu \mathrm{L}$ PCR mix, $0.3 \mu \mathrm{L}$ masing-masing primer (refferencereverse, alternate-reverse, forward-reverse), $4 \mu \mathrm{L}$ DNA dan ultra purewater $\left(\mathrm{ddH}_{2} \mathrm{O}\right)$ steril ditambahkan sehingga volume akhir menjadi $13 \mu \mathrm{L}$. Amplifikasi DNA menggunakan mesin PCR BioRad T100 ${ }^{\mathrm{TM}}$ Thermal Cycler. Amplifikasi DNA diawali dengan satu siklus tahap pre-denaturasi $95^{\circ} \mathrm{C}$ selama 3 menit, diikuti dengan 35 siklus yang terdiri atas: tahapan denaturasi pada suhu $95^{\circ} \mathrm{C}$ selama 15 detik, penempelan primer pada suhu $48^{\circ} \mathrm{C}-60^{\circ} \mathrm{C}$ selama 15 detik (sesuai suhu annealing primer), pemanjangan primer pada suhu $72^{\circ} \mathrm{C}$ selama 1 detik. Pada tahap akhir proses PCR dilakukan pemanjangan akhir pada $72^{\circ} \mathrm{C}$ selama 10 menit. Produk PCR dipisahkan berdasarkan ukuran menggunakan gel agarosa 2\% (Vivantis Inc., USA) dalam 1x SB buffer pada arus konstan sebesar 50 volt selama 30 menit. Ukuran produk amplifikasi diestimasi dengan perbandingan DNA ladder $100 \mathrm{pb}$ (Vivantis Inc., USA). Pita DNA divisualisasi menggunakan pewarnaan $33 \%$ (v/v) GelreD ${ }^{\mathrm{TM}}$ (Biotium Inc.) di bawah lampu UV (Vilber Lourmat Super Bright TFX-20 MX, Sigma-Aldrich) dan didokumentasikan dengan kamera digital.

Validasi produk hasil amplifikasi PCR untuk lokus Indels dilakukan menggunakan elektroforesis gel poliakrilamid $6 \%$ menggunakan buffer SB 1x (Brody dan Kern 2004) dan pewarnaan gel dengan perak nitrat. Tahapan pewarnaan gel dengan perak nitrar dilakukan mengikuti metode Creste et al. (2001) yang dimodifikasi (Tinche et al. 2014 Visualisasi menggunakan UV transluminesen dan elektroforegram di foto menggunakan kamera digital. Penentuan genotipe setiap individu yang dievaluasi dilakukan berdasarkan skoring keragaman alel.

\section{HASIL DAN PEMBAHASAN}

\section{Desain primer untuk menghasilkan marka SNAP dan indels pada situs-situs genom kloroplas yang teridentifikasi}

Ketersediaan sekuen genom kloroplas kelapa, kurma dan kelapa sawit

Sekuen cpDNA tanaman palma yaitu kelapa, kurma dan kelapa sawit didapatkan melalui tiga cara yaitu dengan penelusuran melalui jurnal yang telah dipublikasikan, melalui situs https://www.ncbi.nlm.nih.gov/ dan melalui personal communication dengan Prof. Dr. Ir. Sudarsono, M.Sc. Pada penelusuran melalui situs tersebut disusun dalam format fasta agar dapat disejajarkan dalam multiple sequence alignment seperti yang tercantum pada Tabe 1. Beberapa sekuen tanaman palma yang digunakan yaitu pada kelapa, kurma dan kelapa sawit untuk melihat beberapa variasi SNP dan Indel antara tanaman kelapa dengan tanaman kelapa (Intraspesies) dan tanaman kelapa dan tanaman palma lainnya (Interspesies).

Multiple Sequence Alignment dan Indentifikasi SNP dan Indels

Sekuens genom tanaman palma disusun dalam file teks menurut format fasta. Kemudian sekuens tersebut disejajarkan menggunakan multiple alignment oleh program Geneious Pro 5.6.6 versi percobaan (Biomatters, USA). Multiple alignment tersebut bertujuan untuk mengidentifikasi persebaran SNP dan Indel di dalam sekuen. Identifikasi keberadaan SNP pada Gambar 2 dengan cara memilih sekuen yang memiliki dua jenis basa nukleotida yang berbeda yang memiliki 
karakter bi-alelik, yang mana menggambarkan dua kromosom homolog dari individu diploid. Pada penentuan indels, maka yang dilihat adalah adanya variasi insersi dan delesi yaitu ditemukan adanya bagian basa yang hilang dan yang terisi (Gambar 3).

Tabel 1 Daftar Sekuens (Asal) Genom Kelapa, Kurma dan Kelapa Sawit

\begin{tabular}{lllll}
\hline No & \multicolumn{1}{c}{ ID Aksesi } & $\begin{array}{c}\text { Ukuran } \\
\text { Sekuens }\end{array}$ & Spesies Tanaman & \multicolumn{1}{c}{ Sumber } \\
\hline 1. & CT Cn & 158.462 & Cocos nucifera & Personal communication \\
2. & KF285453.1 Cn & 154.731 & Cocos nucifera & Huang et al. 2013 \\
3. & KX028884.1 Cn & 154.740 & Cocos nucifera & Personal communication \\
4. & NC_022417.1 Cn & 154.731 & Cocos nucifera & https://www.ncbi.nlm.nih.gov/ \\
5. & FJ212316.3 DP & 158.458 & Phoenix dactylifera & https://www.ncbi.nlm.nih.gov/ \\
6. & GU811709.2 DP & 158.462 & Phoenix dactylifera & Yang et al. 2010 \\
7. & NC_013991.2 DP & 158.462 & Phoenix dactylifera & https://www.ncbi.nlm.nih.gov/ \\
8. & JF274081.1 OP & 156.973 & Elaeis guineensis & Uthaipasanwong et al. 2012 \\
9. & NC_017602.1 OP & 156.973 & Elaeis guineensis & https://www.ncbi.nlm.nih.gov/ \\
\hline
\end{tabular}

Pada pola variasi baik SNP maupun Indels, ditemukan adanya tiga pola pada sebagian besar sekuens. Pola yang pertama menunjukkan adanya kesamaan variasi antara genom CT Cn dengan FJ212316.3 DP, GU811709.2 DP dan NC_013991.2 DP. Kemudian, pola yang kedua ditemukan adanya kesamaan variasi SNP antara genom CT $\mathrm{Cn}$ dengan semua genom kecuali JF274081.1 OP dan NC_017602.1 OP. Selanjutnya pola ketiga adalah genom CT Cn sama dengan semua kecuali KF285453.1 Cn, KX028884.1 Cn dan NC_022417.1 Cn. Hal ini dapat dipakai sebagai pertimbangan dalam pemilihan primer yang akan digunakan dalam penelitian selanjutnya.

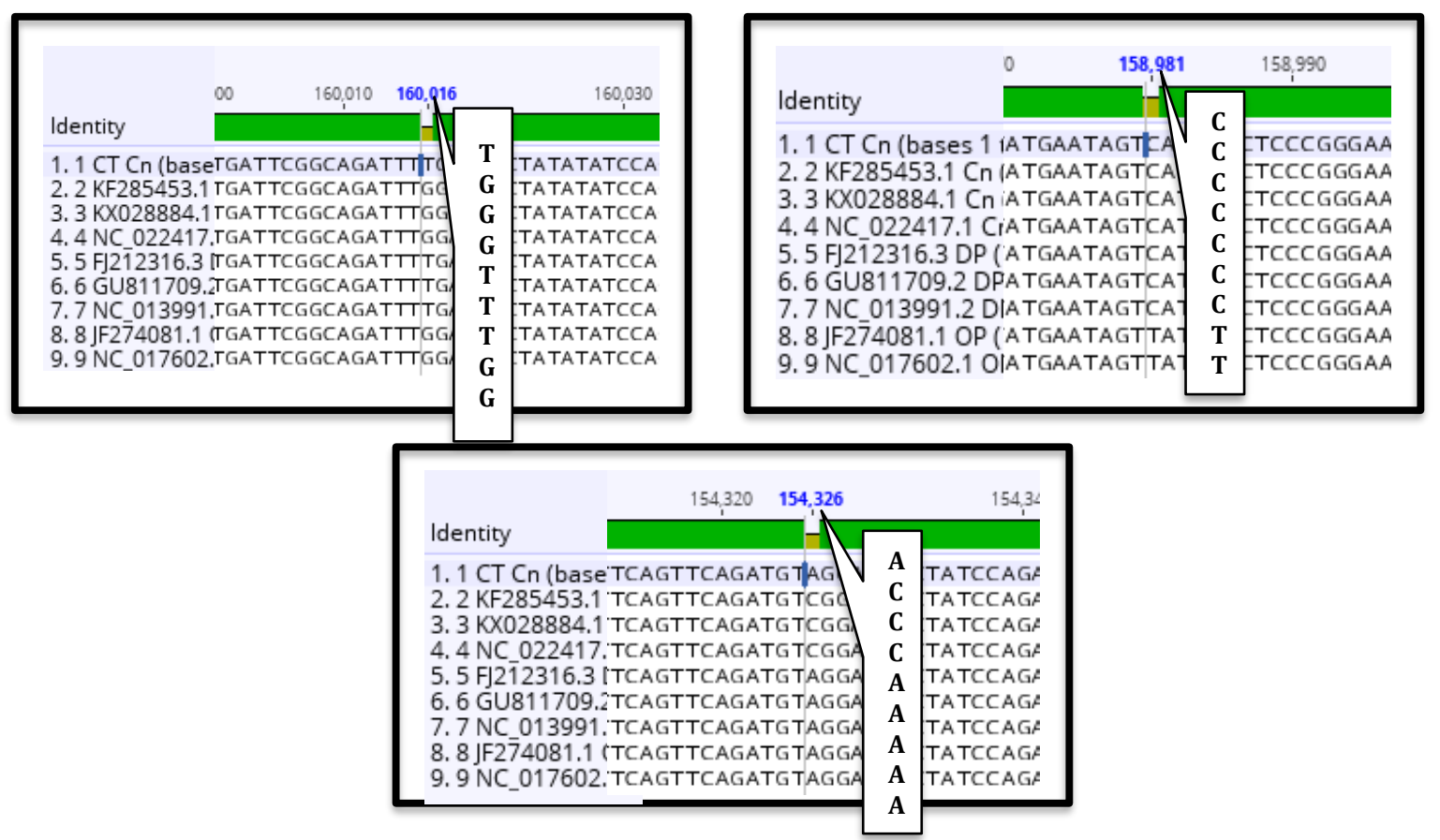

Gambar 2 Penampilan Multiple Sequence Alignment genom tanaman palma yang menunjukkan adanya SNP dengan representatif tiga variasi pola SNP yang berbeda. 
Desain Primer SNAP berdasarkan SNP

Pada dasarnya, SNAP merupakan marka berdasarkan variasi perubahan satu basa (A, T, G, C) pada situs-situs tertentu dari runutan basa DNA dalam genom organisme (Ganal et al. 2009). Polimorfisme SNP tersedia melimpah dan terdistribusi secara merata pada genom organisme hidup sehingga mudah dimanfaatkan dalam analisis untuk mengidentifikasi keragaman yang tinggi
(Peterson et al. 2014). Perkembangan teknologi memberikan peluang untuk mengakses keragaman tersebut berdasarkan data genetik dengan beberapa keunggulan diantaranya tidak terpengaruh fluktuatif terhadap lingkungan dan dapat menunjukkan posisi spesifik keragaman genetik antar spesies yang kemudian dapat dikaitkan dengan keragaman fenotipik (Haristianita 2017).

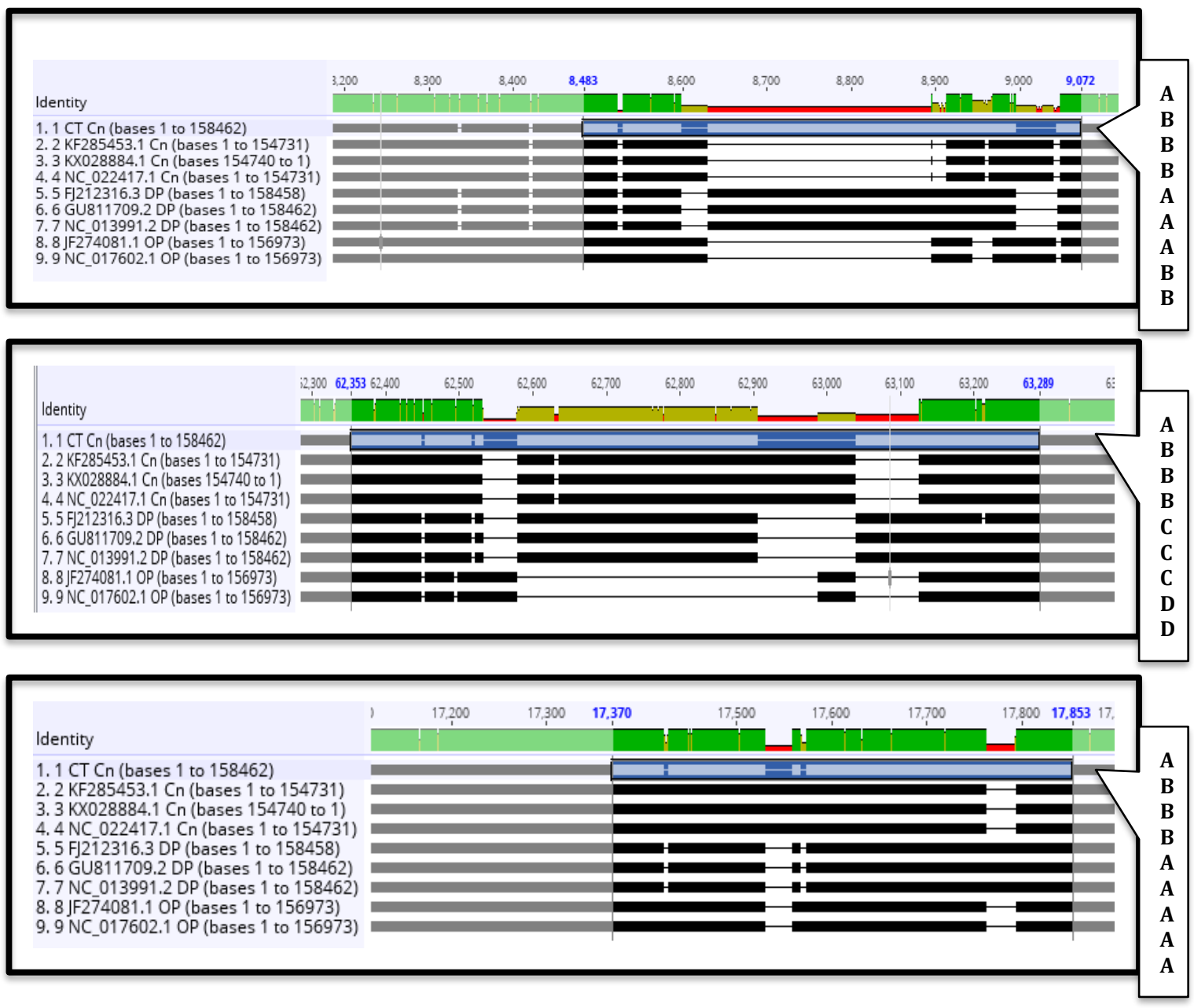

Gambar 3 Penampilan Multiple Sequence Alignment Genom Tanaman Palma yang Menunjukkan adanya Indels dengan Representatif Tiga Variasi Pola Indels yang Berbeda.

Pemilihan pasangan primer dilakukan dengan memperhatikan beberapa hal yaitu suhu Tm tidak jauh berbeda dan posisi mismatch berada pada satu sampai empat nukleotida dari situs SNP (Sutanto et al. 2013). Posisi mismatch adalah satu nukleotida yang berbeda selain pada situs SNP dari primer forward terhadap sekuen aslinya. Posisi mismatch dari ujung 3' sangat berpengaruh terhadap keberhasilan amplifikasi DNA (Bru et al. 2008). Semakin dekat mismatch dengan ujung 3' 
semakin besar kegagalan mendapatkan produk PCR. Berdasarkan hal tersebut, primer SNAP yang dipilih adalah primer dengan posisi mismatch paling jauh dari ujung 3'. Setiap situs SNP diperlukan dua pasangan primer, pasangan pertama primer forward dan reverse untuk alel referensi sedangkan pasangan kedua primer forward dan reverse untuk alel alternatif. Namun, untuk penguunaan primer reverse hanya akan dipilih satu yang dapat digunakan primer referensi dan alternatif sekaligus. Hal ini dikarenakan sebagian besar primer reverse yang ditemukan sama dan untuk menghemat pemakaian primer dalam reaksi pada PCR dalam penelitian selanjutnya. Maka dari itu, pada Tabel 4.2 dibawah ini menunjukkan dalam 10 situs SNP dihasilkan 20 pasang primer SNAP terpilih sesuai dengan kriteria yang telah ditetapkan diatas.

Tabel 2 Daftar primer SNAP berdasarkan genom kloroplas kelapa

\begin{tabular}{|c|c|c|c|c|c|}
\hline No. & Id Primer & Sekuens primer & $\begin{array}{r}\mathrm{Tm} \\
\left({ }^{\circ} \mathrm{C}\right) \\
\end{array}$ & $\begin{array}{c}\text { Panjang } \\
\text { Primer }\end{array}$ & $\begin{array}{c}\text { Ukuran } \\
(\mathrm{pb})\end{array}$ \\
\hline \multirow[t]{3}{*}{1} & CT_SNP1_REF & CACATGAGTGGATATATAGGAATCA & 53 & 25 & 176 \\
\hline & CT_SNP1_ALT & CACATGAGTGGATATATAGGATTCC & 54 & 25 & 176 \\
\hline & CT_SNP1_REV & ATGTCTCCTACGTTACCCGTAATA & 55 & 24 & \\
\hline \multirow[t]{3}{*}{2} & CT_SNP2_REF & ATGCATAAGGATGTTGTGGTCT & 54 & 25 & 190 \\
\hline & CT_SNP2_ALT & ACTTAGTTTCCGCCTGGGT & 54 & 20 & 188 \\
\hline & CT_SNP2_REV & GCATAAGGATGTTGTGGTCC & 55 & 19 & \\
\hline \multirow[t]{3}{*}{3} & CT_SNP3_REF & ACGAAACACTTGGTTTCGATC & 55 & 21 & 175 \\
\hline & CT_SNP3_ALT & CCACGAAACACTTGGTTTCTATT & 56 & 23 & 177 \\
\hline & CT_SNP3_REV & GCTATCGGCCCAGTGAATA & 54 & 19 & \\
\hline \multirow[t]{3}{*}{4} & CT_SNP4_REF & GCGAGAATTAATTATTGGGCAC & 56 & 22 & 161 \\
\hline & CT_SNP4_ALT & CAGCGAGAATTAATTATTGGTGAT & 55 & 24 & 161 \\
\hline & CT_SNP4_REV & CCTCGTTcCTGAAAAGTAGTCA & 54 & 22 & \\
\hline \multirow[t]{3}{*}{5} & CT_SNP5_REF & GAGTCATGGATACAGGAGCCT & 54 & 21 & 185 \\
\hline & CT_SNP5_ALT & TAAAGATCCTCATTGGTGCG & 55 & 20 & 184 \\
\hline & CT_SNP5_REV & AGTCATGGATACAGGAGCCC & 54 & 20 & \\
\hline \multirow[t]{3}{*}{6} & CT_SNP6_REF & TCAGTGATCAAATCATTCATACCA & 55 & 24 & 182 \\
\hline & CT_SNP6_ALT & TTTGTTGGGGATAGAGGGAC & 54 & 23 & 181 \\
\hline & CT_SNP6_REV & CAGTGATCAAATCATTCATACCC & 55 & 20 & \\
\hline \multirow[t]{3}{*}{7} & CT_SNP7_REF & CATTTCGTGACTTATTGGTAAATTT & 54 & 24 & 189 \\
\hline & CT_SNP7_ALT & TTTATCGATATGAGTGTTCTATATCA & 55 & 23 & 189 \\
\hline & CT_SNP7_REV & CATTTCGTGACTTATTGGTAAATTG & 51 & 20 & \\
\hline \multirow[t]{3}{*}{8} & CT_SNP8_REF & CCAGAAAGAATTCAGTTCAGAAGTA & 55 & 25 & 180 \\
\hline & CT_SNP8_ALT & CAGAAAGAATTCAGTTCAGAGGTC & 55 & 24 & 179 \\
\hline & CT_SNP8_REV & СTTTTCCTTCTTCTTGTTGCTG & 54 & 22 & \\
\hline \multirow[t]{3}{*}{9} & CT_SNP9_REF & CGGAACAAGTAAACACTATTTTCAA & 55 & 25 & 178 \\
\hline & CT_SNP9_ALT & GAAATCTCATTCGTACTCATAACTCA & 56 & 26 & 179 \\
\hline & CT_SNP9_REV & CCGGAACAAGTAAACACTATTTACAG & 54 & 26 & \\
\hline \multirow[t]{3}{*}{10} & CT_SNP10_REF & AAGGTATGGAACCCGAGTAAG & 53 & 21 & 177 \\
\hline & CT_SNP10_ALT & CCAATACATCGCAGGGTTC & 55 & 22 & 178 \\
\hline & CT_SNP10_REV & CAAGGTATGGAACCCGAGATAC & 56 & 19 & \\
\hline
\end{tabular}

Marka SNAP adalah teknik molekuler berbasis PCR yaitu mengamplifikasi bagian SNP terseleksi dan bersifat spesifik (Park et al. 2007). Total 10 set primer SNAP dikembangkan dari total 9 fragmen sekuen genom CT Cn, KF285453.1 Cn, KX028884.1 Cn, NC_022417 Cn, FJ212316.3 DP, GU811709.2 DP, NC_013991.2 DP,
JF274081.1 OP dan NC_017602.1 OP. Tidak semua keragaman nukleotida dikembangkan untuk diakses menggunakan marka SNAP, hanya 10 titik SNP (lokus) yang mengarah potensial yang terpilih untuk tiap fragmen karena mewakili tiga pola variasi yang sebagian besar ditemukan pada sekuens genom tersebut.

Primer SNAP yang telah didesain 
tersebut memiliki suhu annealing sekitar $53-55^{\circ} \mathrm{C}$ yang mana suhu tersebut termasuk dalam kriteria suhu annealing yang ideal yaitu $50-60^{\circ} \mathrm{C}$. Namun pada tahap selanjutnya, semua pasangan primer diuji menggunakan singleplex PCR untuk estimasi suhu annealing yang optimal dan memastikan amplifikasi fragmen yang benar (Sint et al. 2012). Pada ukuran primer-primer tersebut berkisar antara 175 pb hingga 190 bp. Hal ini sesuai dengan prinsip teknologi marka SNAP berdasarkan teknik PCR, menggunakan primer spesifik untuk amplifikasi situs-situs SNP pada segmen DNA dengan ukuran berkisar antara 100-500 basa dan hasil amplifikasinya diidentifikasi menggunakan metode standar elektroforesis gel agarosa (Rafalski 2012).

Suatu lokus SNP dianggap potensial jika merupakan mutasi substitusi synonimous yaitu merubah pembacaan asam aminonya. Namun situs SNP nonsynonimous juga dianggap sama-sama memiliki potensi untuk dikembangkan menjadi marka SNAP terseleksi, karena perbedaan kodon yang berbeda akan menghasilkan sifat protein yang berbeda pula yaitu protein bersifat hidrofobik maupun hidrofilik, sifat masing-masing protein dapat merubah struktur ikatan 3 dimensi protein dan akhirnya berpeluang pula untuk mempengaruhi pengenalan protein terhadap substrat (ekspresi protein/katalisasi enzim sesuai atau tidak sesuai) (Saito et al. 2013; Shastry 2009). Pertimbangan lain seperti posisi antar lokus SNP dan jumlah haplotipe (genotipe khas) yang mampu mengelompokkan genotipe asal sekuen masing-masing menjadi kelompok-kelompok yang unik tersendiri juga dapat menjadi dasar untuk mendeleksi SNP yang berpotensi untuk dikembangkan menjadi marka SNAP.

\section{Desain Primer Indels}

Indels merupakan penanda genetik berbasis urutan lainnya seperti SSR dan SNPs dan dikenal sebagai sistem penanda yang efektif untuk analisis genetika pada tanaman karena bersifat multi-allelik dan co-dominant dan distribusi genetika yang luas serta penanda Indel mudah terdeteksi pada skala genom (tingkat gen) (Das et al. 2015). Pada dasarnya, prinsip desain primer Indels adalah dengan melihat variasi insersi dan delesi pada sekuens genom yang telah disejajarkan dengan multiple sequence alignment dengan menggunakan program GENEIOUS. Selanjutnya terpilih 5 situs InDels yang mewakili tiga variasi pola sekuens dan diolah menggunakan program Primer3plus. Maka dari itu didapatkan lima pasang primer foward dan reverse tersedia pada Tabel 3 dibawah ini dengan kriteria hampir sama dengan primer SNAP sebelumnya dengan suhu Tm sekitar 51$60^{\circ} \mathrm{C}$ yang mana suhu tersebut termasuk dalam kriteria suhu annealing yang ideal yaitu $50-60^{\circ} \mathrm{C}$.

Tabel 3 Daftar Primer Indels Berdasarkan Genom Kloroplas Kelapa

\begin{tabular}{cllccc}
\hline No & Id Primer & \multicolumn{1}{c}{ Sekuens primer } & Tm & $\begin{array}{c}\text { Panjang } \\
\text { Primer }\end{array}$ & $\begin{array}{c}\text { Ukuran } \\
(\mathrm{pb})\end{array}$ \\
\hline \multirow{2}{*}{1} & CT_InDels1_F & TTCCATAATCTCATTGTTTTT & 51.7 & 21 & 410 \\
& CT_InDels1_R & ACTGTTTGGATCTGTGTGA & 51.8 & 19 & 410 \\
2 & CT_InDels2_F & GAAAGAGACTTTCATTTCCAGTC & 56.3 & 23 & 410 \\
& CT_InDels2_R & CCAAGGGCTATAGTCATAGTGAT & 56.5 & 23 & 410 \\
3 & CT_InDels3_F & AAACCTTCTATCAACAGGAT & 50.4 & 20 & 887 \\
& CT_InDels3_R & AAATAGAGGGTAAGTTGAGATCTGT & 56.0 & 25 & 887 \\
\multirow{2}{*}{4} & CT_InDels4_F & AAGATTTTGTTCAGCATGTTCT & 55.7 & 22 & 234 \\
& CT_InDels4_R & AAAAAGGGCGTGGAAACAC & 60.0 & 19 & 234 \\
5 & CT_InDels5_F & AGACGAAGAGAAAGGTCTATCC & 55.8 & 22 & 234 \\
& CT_InDels5_R & TCAAAACACTATGTATGGATGA & 53.2 & 22 & 234 \\
& & & & & \\
\hline
\end{tabular}


Namun suhu tersebut perlu dioptimasi kembali pada PCR (Polymerase Chain Reaction) agar didaptkan suhu yang sesuai dengan penempelan primer yang optima (Sint et al. 2012). Apabila ditemukan high self / high end self complementary juga tidak akan dipilih karena primer tersebut akan tidak bisa digunakan.

\section{Validasi Primer SNAP dan Indels}

Primer berperan penting dalam menghasilkan produk amplifikasi karena dipengaruhi oleh karakter primer seperti stabilitas internal, suhu melting, struktur sekunder atau kompetisi antar primer (Sint et al. 2012). Kemampuan primer SNAP berdasarkan situs SNPs dan Indels yang telah berhasil dikembangkan perlu diuji. Validasi primer tersebut menggunakan DNA Kelapa Bido dan Kelapa Dalam Morotai melalui PCR. Hasil amplifikasi DNA dengan menggunakan 10 pasang primer tersebut disajikan dalam Gambar 4.
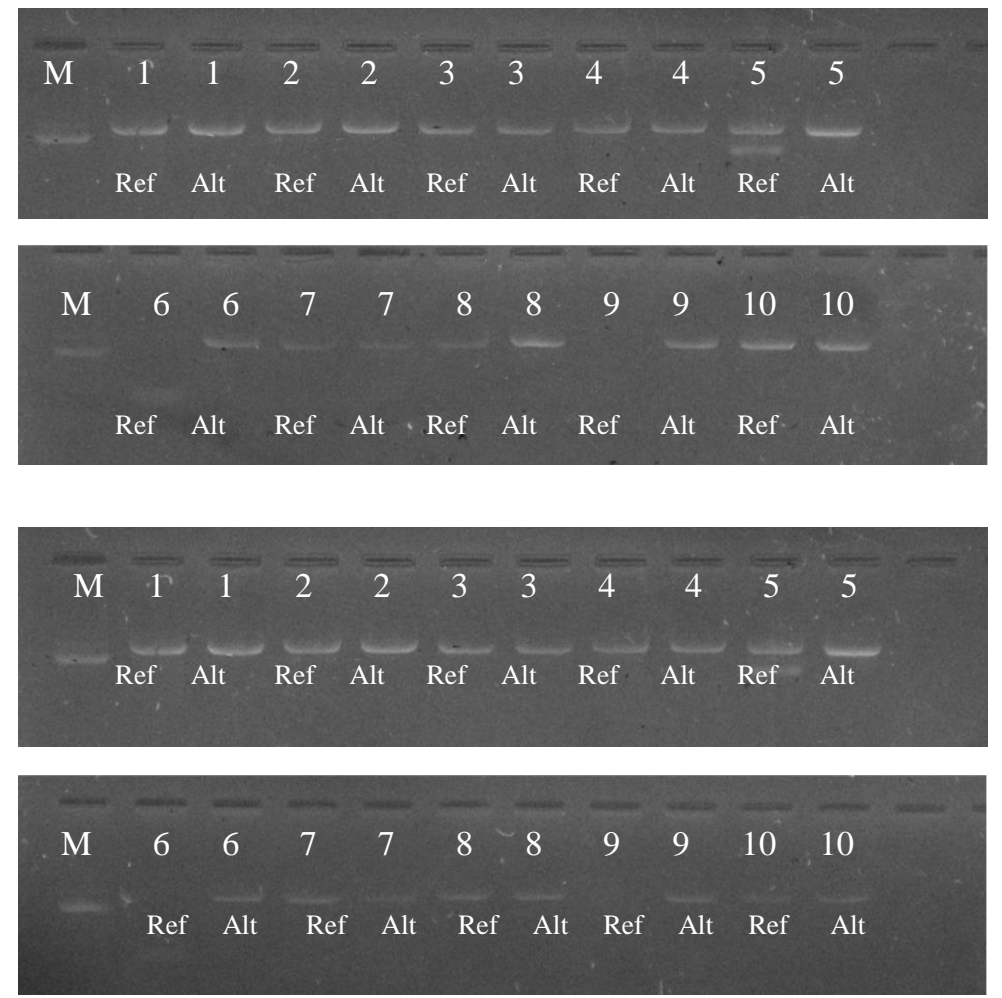

Kelapa Bido

Kelapa Dalam Morotai

Gambar 4 Hasil amplifikasi 10 primer SNAP terhadap DNA Kelapa Bido dan Kelapa Dalam Morotai. Marker:100pb

Semua primer SNAP berdasarkan situs SNPs menghasilkan produk atau pita yang jelas yang mana pada kedua alel reference dan alternate muncul, kecuali pada primer SNP6 dan SNP9. Pada gambar tersebut alel tidak muncul pada alel reference. Ada dua kemungkinan penyebab alel tersebut tidak muncul. Pertama, DNA tersebut tidak teramplifikasi oleh primer SNP6 dan SNP9. Kedua, terjadi kesalahan teknis dalam pembuatan koktail PCR mix. Untuk mengonfirmasi hal tersebut, maka telah dilakukan validasi ulang. Hasil dari validasi tersebut menyatakan bahwa muncul pita. Hal ini membuktikan bahwa memang terjadi kesalahan teknis. Hal ini diperkuat dengan uji primer-primer SNP pada 94 aksesi kelapa Bido, Lokal Morotai dan Kelapa Unggul Indonesia.

Hasil amplifikasi pada populasi kelapa tersebut ialah bahwa seluruh aksesi muncul pita pada ukuran sesuai dengan primer masing-masing. Terutama pada SNP6 dan SNP9 yang pada awalnya tidak muncul, maka pada populasi tersebut muncul pita pada alel reference maupun 
alternate, contoh profil alel dapat dilihat pada Gambar 6. Genom kloroplas merupakan genom yang bersifat haploid, oleh karena sifat tersebut alel yang muncul diharapkan hanya salah satu dari alel reference atau alternate. Namun, dalam penelitian ini didapatkan hasil bahwa pita tersebut muncul disemua alel.

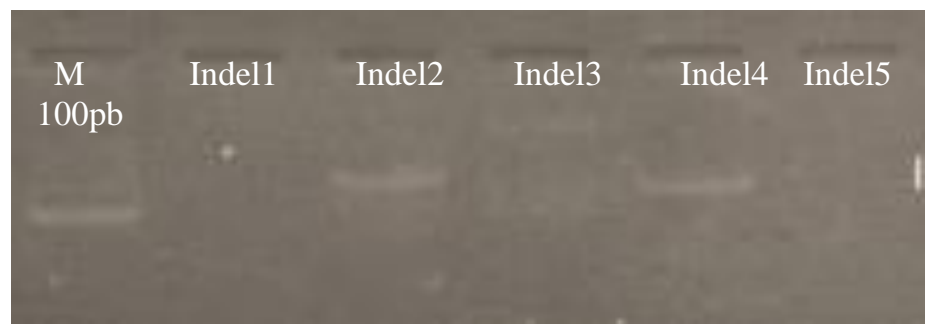

Gambar 5 Hasil amplifikasi 5 primer Indels terhadap DNA Kelapa Bido. Marker: 100pb

Ada beberapa hal yang menyebabkan hal demikian yaitu dapat diduga bahwa terdapat genom kloroplas lain yang teramplifikasi dan memiliki motif yang sama dengan primer yang diuji atau dalam genom kloroplas tersebut telah terjadi mutasi yaitu duplikasi.
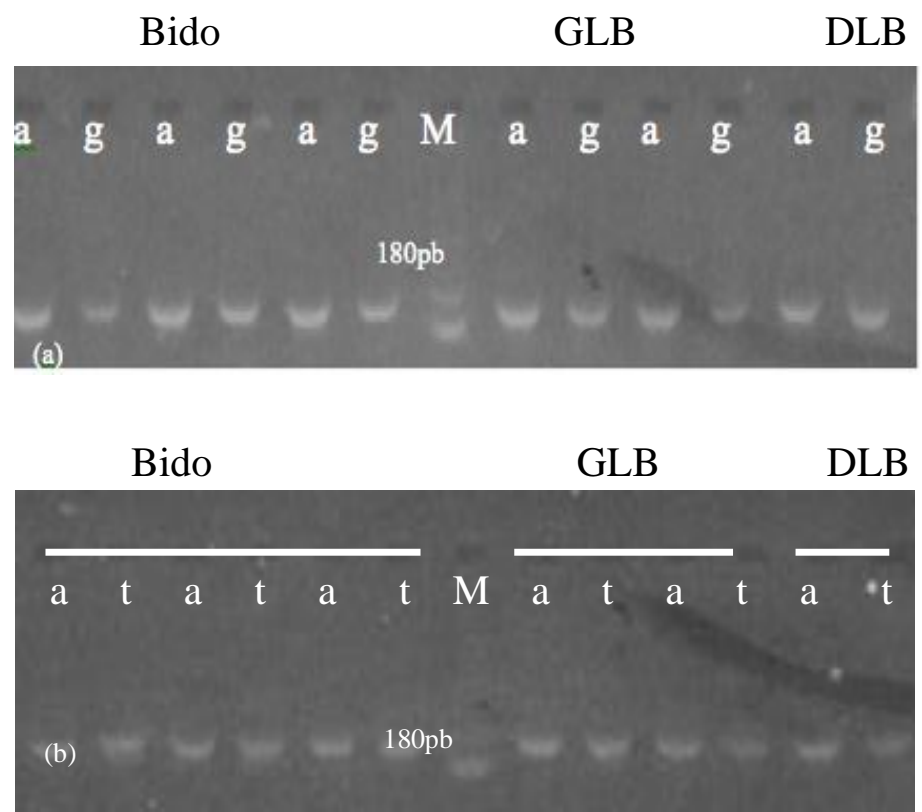

Gambar 6 Profil alel hasil amplifikasi populasi Kelapa Morotai menggunakan primer SNP6 (a) dan SNP9 (b). Marker: 100pb

Pada primer Indels, primer yang dapat teramplifikasi hanya primer InDels2 dan InDels4 (Gambar 5) Setelah dilakukan optimasi pada InDels1, InDels3 dan InDels5 pada suhu $45-55^{\circ} \mathrm{C}$ pita tersebut juga tidak muncul. Penyebab ketiadaan pita tersebut diduga karena pada semua populasi tidak terdapat alel yang merepresentasikan primer tersebut atau ketidaksesuaian suhu pada optimasi. Primer InDels2 dan InDels4 mampu mengamplifikasi seluruh aksesi pada populasi kelapa sama halnya dengan primer SNP pada ukuran yang sesuai dengan primer tersebut pada gel agarose $2 \%$.

Pada primer indel perlu dilakukan elektroforesis secara vertikal agar alel dapat terpisah secara sempurna karena beberapa ukuran dari insersi maupun delesi kurang dari 10-20bp (Gambar 7), sehingga jika menggunakan gel agarose tidak mampu memisahkan alel kurang dari 100bp. Oleh 
karena itu, proses validasi dilanjutkan menggunakan elektroforesis gel poliakrilamid $6 \%$.

Visualisasi

menggunakan

eletroforesis gel poliakrilamid 6\% terhadap

20 aksesi Kelapa Morotai dengan pewarnaan perak nitrat telah dilakukan pada primer InDels2. Hasil dari elektroforesis tersebut juga menunjukkan bahwa terdapat satu pita yang muncul pada ukuran yang sama yaitu 410pb (Gambar 7).

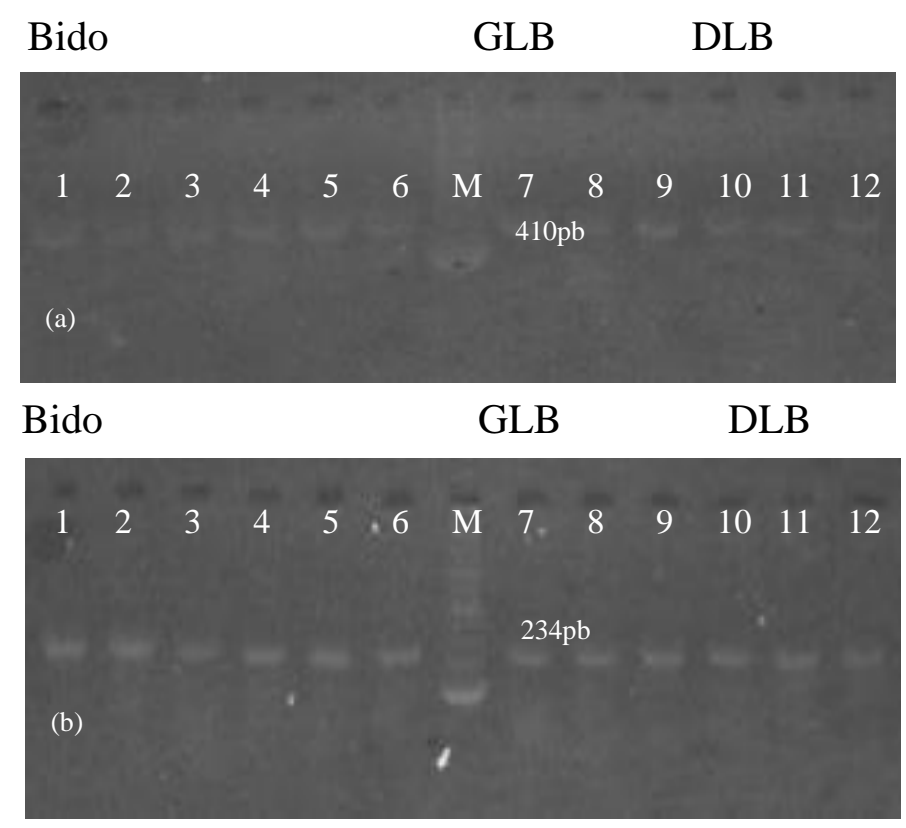

Gambar 7 Profil alel hasil amplifikasi populasi Kelapa Morotai menggunakan primer Indel2 (a) dan Indel4 (b). Marker: 100pb

Berdasarkan empat genom kloroplas kelapa yang berasal dari Huang et al. (2013), bank gen NCBI dan personal communication (Tabel 1) pada dasarnya terdapat dua jenis haplotipe yang berbeda (Gambar 1 dan Gambar 2). Selanjutnya, dari haplotipe berbeda tersebut diuji ke 94 aksesi kelapa Indonesia. Keberadaan pitapita tersebut membuktikan bahwa semua aksesi kelapa yang diuji mempunyai sekuens kloroplas yang sama.
Representasi kelapa dengan kloroplas tipe yang lain tidak ditemukan dalam sampel kelapa yang diuji. Hal ini dapat diduga bahwa dari DNA kloroplas kelapa yang diuji hanya merupakan representasi salah satu dari haplotipe kloroplas yang ada. Untuk mengonfirmasi kelapa yang diuji merupakan representasi haplotipe yang mana maka perlu dilakukan sequencing untuk target DNA yang dievaluasi.

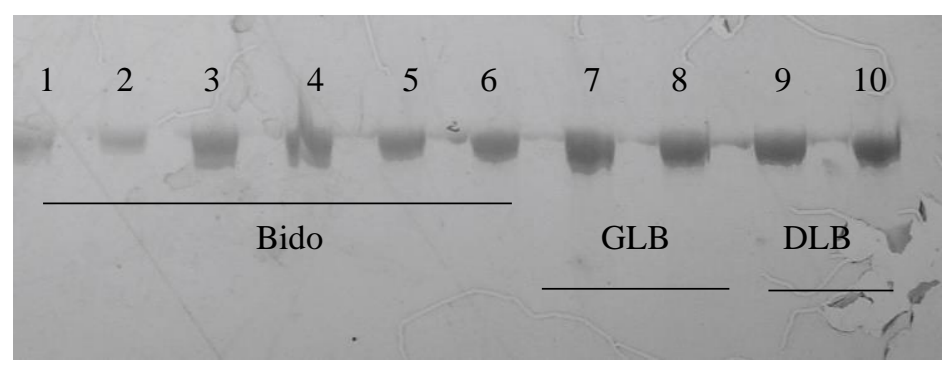

Gambar 8 Profil alel hasil amplifikasi Kelapa Morotai menggunakan primer Indel2 dengan elektroforesis gel akrilamid 6\% 


\section{KESIMPULAN}

Berdasarkan sembilan sekuens genom kloroplas pada tanaman palma, telah berhasil didisain 10 primer berdasarkan situs SNP dan 5 primer berdasarkan situs

\section{DAFTAR PUSTAKA}

Batugal P, Rao VR, Oliver J, editors. 2005. Coconut Genetic Resources. Serdang (MY). International Plant Genetic Resources Institute - Regional Office for Asia, the Pacific and Oceania (IPGRI-APO).

Bru D, Martin-Laurent F, Philippot L. 2008. Quantification of the detrimental effect of a single primertemplate mismatch by real-time PCR using the 16s rRNA gene as an example. App Env Microbiol. 74(5):1660-1663.

Das S, Upadhyaya HD, Srivastava R, Bajaj D, Gowda CLL, Sharma S, Singh S, Tyagi AK, Parida SK. 2015. Genome-wide insertion-deletion (InDel) marker discovery and genotyping for genomics-assisted breeding applications in chickpea. DNA Research. 22:377-386.

Dauby G, J Duminil, M Heuertz, O. J. Hardy. 2010. Chloroplast DNA Polymorphism and Phylogeography of a Central African Tree Species Widespread in Mature Rainforests: Greenwayodendron suaveolens (Annonaceae). $J$ Tropical Plant Biol. 3:4-13.

Ganal MW, Altmann T, Roder MS. 2009. SNP identification in crop plant. Curr Opin Plant Biol. 12: 211-217.

Gunn BF 2016. Phylogenomics of Coconut (Cocos nucifera). [Disertasi]. Canberra (AU): The Australian National University.

Haristianita MD. 2017 Gen Terkait Warna Bunga: Pemanfaatannya untuk Pengembangan Marka Molekuler dan Analisis Genetik Warna Bunga insersi delesi. Hasil validasi primer tersebut menggunakan DNA kelapa Indonesia didapatkan hasil bahwa 10 primer SNP berhasil teramplifikasi sedangkan indels hanya 2 primer berbasis PCR.

Phalaenopsis. [Disertasi]. Bogor (ID): Institut Pertanian Bogor.

Huang LS, Sun YQ, Jin Y, Gao Q, Hu XG, Gao FL, Yang XL, Zhu JJ, ElKassaby Y, Mao JF. 2018. Development of high transferability cpSSR markers for individual identification and genetic investigation in Cupressaceae species. Ecol and Evol. 8: 4967-4977.

Huang Y, Matzke AJM, Matzke M. 2013. Complete sequence and comparative analysis of the chloroplast genome of coconut palm (Cocos nucifera). Plos One 8(8):

Hu J, Gui S, Zhu Z, Wang X, Ke W, Ding Y. 2015. Genome- wide identification of SSR and SNP markers based on whole-genome resequencing of a Thailand wild sacred lotus (Nelumbo nucifera). Plos One. 1-17.

Jia SW, Zhang ML, Raab-Straube EV, Thulin M. 2016. Evolutionary history of Gymnocarpos (Caryophyllaceae) in the arid regions from North Africa to Central Asia. The Linnean Society of London, Biological Journal of the Linnean Society.

Larekeng SH, Maskromo I, Purwito A, Mattjik NA, Sudarsono. 2015. Pollen dispersal and pollination patterns studies in Pati kopyor coconut using molecular markers. Intl J Coconut Res Dev. 31(1): 46-60.

Loiola CM. Azevedo AON, Diniz LEC, Aragão WM, Azevedo CDO, Santos PHAD, Ramos HCC, Pereira MG, Ramos SRR. 2016. Genetic relationships among tall coconut palm (Cocos nucifera L.) accessions of the international coconut genebank for Latin America and the Caribbean 
(ICG-LAC), evaluated using microsatellite markers (SSRs). Plos One. 11(3):1-11.

Novarianto H. 2010. Karakteristik bunga dan buah hasil persilangan kelapa hibrida genjah $\mathrm{x}$ genjah. Buletin Palma. 39:100-110.

Park J, Park BY, Kim HS, Lee JE, Suh I, Nam CM, Beaty TH. 2007. MSXI Polymorphism Associated with Risk of Oral Cleft in Korea: Evidence from Case-Parent Trio and Case-Control Studies. J Yonsei Med, 48(1):101.

Peterson GW, Dong Y, Horbach C, Fu YB. 2014. Genotyping-by-sequencing for plant genetic diversity analysis: a lab guide for SNP genotyping. Diversity. 2014(6):665-680.

Pesik A. 2016. Keragaman Genetik Plasma Nutfah Kelapa Indonesia dan Penentuan Identitas Kelapa Hibrida Berdasarkan Marka Molekuler. [Disertasi]. Bogor (ID): Institut Pertanian Bogor.

Rafalski A. 2012. Application of single nucleotide polymorphism in crop genetics. Curr Opin Plant Biol. 5:94100.

Ren J, Sun D, Chen L, You FM, Wang J,
Nevo E, Sun D, Luo MC, Peng J, Peng Y. 2013. Genetic diversity revealed by single nucleotide polymorphism markers in a worldwide germplasm collection of durum wheat. Intl J Mol Sci. 14: 7061-7088.

Sutanto A, Hermanto C, Sukma D, Sudarsono. 2013. Development of SNAP marker based on resistance gene analogue genomic sequences in banana (Musa spp.) [In Indonesia]. $J$ Horti. 23(4):300-309.

Sint D, Raso L, Traugott M. 2012. Advances in multiplex PCR: balancing primer efficiencies and improving detection success. Methods Ecol Evol. 2012(3):898-905.

Tinche. 2014. Keragaman Genetik Kelapa Sawit Asal Nigeria dan Asosiasi Marka Mikrosatelit (SSR) dengan Karakter Virescens. [Disertasi]. Bogor (ID): Institut Pertanian Bogor.

Yang M, Zhang X, Liu G, Yin Y, Chen K, et al. (2010) The complete chloroplast genome sequence of date palm (Phoenix dactylifera L.). PloS ONE 5: e12762. 